\title{
Chapter 10 \\ Census Coverage of American Indians and Alaskan Natives
}

\begin{abstract}
Overall, the net undercount of American Indians and Alaskan Natives Alone or in Combination is relatively low $(0.2 \%)$ but some subgroups within this population have high net undercount and omissions rates. The omissions rate for American Indians and Alaskan Natives Alone or in Combination was $7.6 \%$ which is double the rate for Non-Hispanic White Alone (3.8\%). Also, Census coverage for American Indians and Alaskan Natives living on reservations was much worse than for this population living elsewhere. The net undercount rate for American Indians Alone and Alaskan Natives or in Combination living on reservations was $4.9 \%$ in the 2010 Census.
\end{abstract}

\subsection{Introduction}

In reporting Census data on the American Indian and Alaskan Native population it is very important to be clear about how the group is defined. Starting in the 2000 Census, people were allowed to select more than one race in the Census questionnaire (U.S. Office of Management and Budget 1997). Given this option, race is often shown two different ways in Census Bureau reports. One category is the number of people who only select American Indian and Alaskan Native (referred to as American Indians and Alaskan Natives Alone) and a second category includes everyone in the first category as well as those who select American Indian and Alaskan Native along with at least one other race (referred to as American Indians and Alaskan Native Alone or in Combination).

The Census Bureau population estimates for 2016 show 4.1 million people identified as American Indian and Alaskan Native Alone and 6.7 million selected American Indian and Alaskan Native Alone or in Combination. American Indian and Alaskan Natives Alone or in Combination is the primary definition for the population examined in this Chapter. This is the most inclusive definition and using it in this Chapter is consistent with advice of the U.S. Office of Management and Budget (2001).

The Demographic Analysis (DA) method does not produce data on Census coverage for American Indians and Alaskan Natives, because this category has not been used consistently in birth and death certificates over time or across states. All the 
data in this section come from the Census Bureau's Dual-Systems Estimates (DSE) method. Keep in mind the sample size of American Indians and Alaskan Natives in the Post-Enumeration Survey used in the DSE method is smaller than most other groups so small differences between rates may not be significant.

\subsection{Undercount of American Indians and Alaskan Natives}

Table 10.1 shows net undercount rates from DSE for American Indians and Alaskan Natives Alone or in Combination and Non-Hispanic Whites Alone broken down by age and sex. Data for the children under age 10 are not provided in Table 10.1 because there is strong evidence that the DSE coverage estimates of young children are problematic (O'Hare et al. 2016).

In the 2010 Census, there was a small net undercount (0.2\%) for American Indians and Alaskan Natives Alone or in Combination which was not statistically significantly different from zero. By comparison, there was a statistically significant net overcount of Non-Hispanic White Alone population of $0.8 \%$.

As with all the racial and ethnic groups examined in this publication, the net undercount rate for the total population masks some important differences among age/sex subgroups. However, within the American Indian and Alaskan Native Alone or in Combination population, the differences by age and sex are not as pronounced as they are in the Black and Hispanic populations.

Table 10.1 Net undercount rates for American Indians and Alaskan Natives Alone or in Combination population and Non-Hispanic White Alone population in the 2010 census by age and sex

\begin{tabular}{l|l|l}
\hline & $\begin{array}{l}\text { American Indians and Alaskan Natives } \\
\text { Alone or in Combination }\end{array}$ & $\begin{array}{l}\text { Non-Hispanic White } \\
\text { Alone }\end{array}$ \\
\hline Total & -0.2 & $\mathbf{0 . 8}$ \\
\hline Age $10-17$ & 1.1 & $\mathbf{1 . 8}$ \\
\hline Age $18-29$ male & -1.9 & $\mathbf{1 . 5}$ \\
\hline Age $18-29$ female & $\mathbf{- 2 . 6}$ & $\mathbf{1 . 1}$ \\
\hline Age $30-49$ male & $\mathbf{- 3 . 1}$ & $\mathbf{- 2 . 1}$ \\
\hline Age $30-49$ female & 0.4 & $\mathbf{0 . 7}$ \\
\hline Age 50+ male & 1.5 & $\mathbf{0 . 6}$ \\
\hline Age 50+ female & $\mathbf{4 . 6}$ & $\mathbf{2 . 2}$ \\
\hline
\end{tabular}

Source U.S. Census Bureau (2012a). "2010 Components of Census Coverage for Race Groups and Hispanic Origin by Age, Sex, and Tenure in the United States". DSSD 2010 CENSUS COVERAGE MEASUREMENT MEMORANDUM SERIES\#2010-E-51, U.S. Census Bureau, Washington, DC A negative sign reflects a net undercount. The signs here are reversed from the source report in order to keep directionality consistent within this publication

Figures in BOLD are statistically significantly different from zero 
The highest net undercount rate in Table 10.1 is for American Indian and Alaskan Native Alone or in Combination males age 30-49 where the net undercount rate is $3.1 \%$ which is statistically significant. There is also a high statistically significant net undercount rate for females age 18-29 (2.6\%). On the other hand, there is a large net overcount of American Indian and Alaskan Native Alone or in Combination females over age 50 (4.6\%). It is not clear why older American Indians and Alaskan Natives Alone or in Combination females have such a high net overcount rate. These are the only net coverage estimates for American Indians and Alaskan Natives Alone or in Combination that are statistically significantly different than zero.

\subsection{Census Coverage on Reservations}

One important distinction among American Indians and Alaskan Natives Alone or in Combination with respect to the accuracy of Census counts is whether they live on an Indian Reservation. Data indicate American Indians and Alaskan Natives Alone or in Combination living on Indian reservations have much higher net undercounts than those living elsewhere in the country (U.S. Census Bureau 2012b, Table 7). In the 2010 Census, there were 571,000 American Indians or Alaskan Natives living on Indian Reservations (U.S. Census Bureau 2012b, Table 9).

The net undercount in the 2010 Census for American Indians and Alaskan Natives Alone or in Combination living on reservations was 4.9\%. For American Indians Alone and Alaskan Natives or in Combination living in elsewhere there was a net overcount of $2.0 \%$. The omissions rate for American Indians and Alaskan Natives Alone or in Combination living on reservations was 13.7\% (U.S. Census 2012b, Table 9).

The high net undercount and omissions rates of American Indians and Alaskan Natives living on reservations may reflect the presence of some of the same hard-tocount (HTC) characteristics (high poverty and unemployment rates, unconventional housing, and low levels of literacy, for example) that exist in many HTC urban neighborhoods.

\subsection{Omissions Rates for American Indians and Alaskan Natives}

Recall that the net Census undercount rate is a balance between people omitted and those included erroneously (mostly double counted). The omissions rate captures the share of a group missed in the Census. DSE is the only method that shows omissions rates. 
Table 10.2 Omissions rates for American Indians and Alaskan Natives Alone or in Combination and Non-Hispanic White Alone populations in the 2010 census by age and sex

\begin{tabular}{l|l|l}
\hline & $\begin{array}{l}\text { American Indians and Alaskan Natives } \\
\text { Alone or in Combination }\end{array}$ & $\begin{array}{l}\text { Non-Hispanic White } \\
\text { Alone }\end{array}$ \\
\hline Total & 7.6 & 3.8 \\
\hline Age $10-17$ & 8.1 & 3.1 \\
\hline Age $18-29$ males & 11.2 & 6.6 \\
\hline Age $18-29$ females & 10.3 & 6.2 \\
\hline Age $30-49$ males & 9.9 & 6.2 \\
\hline Age $30-49$ females & 5.5 & 3 \\
\hline Age 50+ males & 5.9 & 3.5 \\
\hline Age 50+ females & 3.2 & 1.7 \\
\hline
\end{tabular}

Source U.S. Census Bureau (2012a). "2010 Components of Census Coverage for Race Groups and Hispanic Origin by Age, Sex, and Tenure in the United States". DSSD 2010 CENSUS COVERAGE MEASUREMENT MEMORANDUM SERIES\#2010-E-51, U.S. Census Bureau, Washington, DC. Table C

In many ways the omissions rate is a more meaningful statistic than the net undercount rate because in the net undercount calculation omissions can be cancelled out by erroneous inclusions or double counting. A net undercount of zero could be the result of no one missed and no one double counted, or for example, ten percent missed, and ten percent double counted.

Examination of omissions rates are particularly important for the American Indians and Alaskan Natives Alone or in Combination population because the very low net undercount could leave people with the impression that almost no American Indians and Alaskan Natives Alone or in Combination were missed in the 2010 Census. The data below show that is not the case.

Omissions rates show much bigger differences between American Indian and Native Alaskans Alone or in Combination and Non-Hispanic Whites Alone than were seen in comparisons of net undercount rates. Table 10.2 shows omissions rates by age and sex for American Indians and Alaskan Natives Alone or in Combination and the Non-Hispanic Whites Alone population. The omissions rate for American Indians and Alaskan Natives Alone or in Combination (7.6\%) is double that of the Non-Hispanic White Alone population (3.8\%).

Data in Table 10.2 show that the omissions rates for American Indians and Alaskan Natives Alone or in Combination are higher than the corresponding cell for NonHispanic Whites Alone in every case. The omissions rates for American Indians and Alaskan Natives Alone or in Combination varies by age and sex and to a large extent the omissions rates reflect the same pattern as the net undercount rates.

Like the results for net undercount rates, American Indian and Alaskan Native Alone or in Combination males age 18-49 had higher omissions rates than any other sex/age subgroup. For young adults (age 18-29) the omissions rates were high for both males and females. The omissions rate for American Indians and Alaskan 
Table 10.3 2010 census net undercount rates and omissions rates for American Indians and Alaskan Natives Alone or in Combination and Non-Hispanic White Alone by Tenure

\begin{tabular}{l|l|l|l}
\hline \multicolumn{2}{l|}{} & $\begin{array}{l}\text { American Indians } \\
\text { and Alaskan Natives } \\
\text { Alone or in } \\
\text { Combination }\end{array}$ & $\begin{array}{l}\text { Non-Hispanic White } \\
\text { Alone }\end{array}$ \\
\hline Percent undercount & $\begin{array}{l}\text { Population living } \\
\text { owner-occupied } \\
\text { housing units }\end{array}$ & 1.3 & $\mathbf{0 . 8}$ \\
\cline { 2 - 4 } & $\begin{array}{l}\text { Population living } \\
\text { renter-occupied } \\
\text { housing units }\end{array}$ & $\mathbf{- 1 . 9}$ & 0.9 \\
\hline
\end{tabular}

Source U.S. Census Bureau (2012a). "2010 Components of Census Coverage for Race Groups and Hispanic Origin by Age, Sex, and Tenure in the United States". DSSD 2010 CENSUS COVERAGE MEASUREMENT MEMORANDUM SERIES\#2010-E-51, U.S. Census Bureau, Washington, DC. Table B

A negative sign reflects a net undercount. The signs here are reversed from the source report in order to keep directionality consistent within this publication

Figures in BOLD are statistically significantly different from zero

Natives Alone or in Combination males age 18-29 was $11.2 \%$ and for females age 18-29 it was $10.3 \%$. The omissions rate for males age 30-49 was 9.9\%. Older American Indians and Alaskan Natives Alone or in Combination (age 50 and over) omissions rates were lower.

\subsection{Coverage of American Indians and Alaskan Natives by Tenure}

Table 10.3 shows net coverage rates and omissions rates from the 2010 Census DSE analysis for the population living in owner-occupied housing units and the population living in renter-occupied housing units among American Indians and Alaskan Natives Alone or in Combination compared to the Non-Hispanic White Alone population.

In terms of net undercount rates, the population of American Indians and Alaskan Natives Alone or in Combination living in owner-occupied housing units had a net overcount of $1.3 \%$ which is slightly higher than that of Non-Hispanic Whites Alone $(0.8 \%)$. On the other hand, American Indian and Alaskan Natives Alone or in Combination living in rental-occupied housing units had a $1.9 \%$ net undercount rate compared to a $0.9 \%$ net overcount for Non-Hispanic Whites Alone living in rental housing units. 
Table 10.4 Net undercount rates for American Indians Alone, Non-Hispanic White Alone in the U.S. Census, 1990, 2000, and 2010

\begin{tabular}{l|l|l|l}
\hline & 2010 & 2000 & 1990 \\
\cline { 2 - 4 } & Undercount rate & Undercount rate & Undercount rate \\
\hline $\begin{array}{l}\text { American Indians Alone living on } \\
\text { reservations }\end{array}$ & $\mathbf{- 4 . 9}$ & 0.9 & $\mathbf{- 1 2 . 2}$ \\
\hline $\begin{array}{l}\text { American Indians Alone living not } \\
\text { living on reservations }\end{array}$ & 2.0 & -0.6 & $\mathbf{- 0 . 7}$ \\
\hline Non-Hispanic White & $\mathbf{0 . 8}$ & $\mathbf{1 . 1}$ & $\mathbf{- 0 . 7}$ \\
\hline
\end{tabular}

Source U.S. Census Bureau (2012a). "2010 Census Coverage Measurement Estimation Report: Summary of Estimates of Coverage for Persons in the United States". DSSD 2010 CENSUS COVERAGE MEASUREMNET MEMORANDUM SERIES\#2010-G-01, U.S. Census Bureau, Washington, DC. Table 7

A negative sign reflects a net undercount. The signs here are reversed from the source report in order to keep directionality consistent within this publication

Figures in Bold are statistically significantly different than zero

In terms of omissions rates, American Indian and Alaskan Natives Alone or in Combination had higher rates than Non-Hispanic Whites Alone for both owners and renters, but the difference was a little larger for owner.

\subsection{Trend Data from 1990 to 2010}

Table 10.4 shows net undercount rates for 1990, 2000, and 2010 Censuses for American Indians Alone and Non-Hispanic Whites Alone based on the Census Bureau's DSE method. The race alone category is used in Table 10.4 because that is the only category available in 1990. The data for American Indians Alone has been broken out by whether or not a person was living on an Indian Reservation because there are big differences between people living on a reservation or somewhere else.

The net undercount rates for American Indians Alone on reservations have been wildly inconsistent from 1990 to 2010. For American Indians Alone living on reservations there was a very high net undercount rate in $1990(12.2 \%)$ but in the 2000 Census the there was a small $(0.9 \%)$ net overcount which is not statistically significantly different from zero. In the 2010 Census there was a statistically significant net undercount rate of $4.9 \%$. It is difficult to discern any trends over time from this data and I am not aware of any explanation for the big swings in Census coverage for American Indians from 1990 to 2010. For American Indians Alone living somewhere other than a reservation there was a small net undercount in 1990 and 2000 but a net overcount in 2010. 


\subsection{Potential Addition of a Question on Citizenship}

It may seem odd to being talking about American Indians and a question on citizenship, but I think it may be more relevant than it first appears. In March 2018, Commerce Secretary Ross (2018) announced that the 2020 Census questionnaire would have a question on citizenship. At the Spring 2018 Meeting of the Census Bureau's National Advisory Committee it was reported that some American Indians would not identify as being citizens of the United States, because they feel they are citizens of their tribal nation. This is consistent with the 2016 American Community Survey, which found 3.3\% of American Indian and Alaskan Natives Alone or in Combination reported they were not a U.S. citizen and $6 \%$ did not provide a response to this question. The nonresponse rate for the citizenship question is much higher than the nonresponse rates for basic demographic characteristics such as age, sex, and race, which suggests in may be a more sensitive question (O'Hare 2018). This is likely to add another (unforeseen) twist to the last-minute addition of the citizenship question to the 2020 Census questionnaire (Ross 2018; Barraba and Flynn 2018).

\subsection{Summary}

Overall, the net undercount of American Indians and Alaskan Natives is relatively low $(0.2 \%)$ but some subgroups within this population have high net undercount and omissions rates. Like most other groups examined in this book, males age 18-49 had the highest net undercount and omissions rates.

In the 2010 Census, the net undercount rate of American Indians living on reservations was very high (4.9\%). Many American Indian reservations have some of the same hard-to-count characteristic (high poverty and unemployment rates, unconventional housing, and low levels of literacy, for example) that exist in many hard-tocount urban neighborhoods.

\section{References}

Barabba, V. \& Flynn, K. H. (January 30, 2018). Ensure everyone is counted. U.S. News.

O'Hare, W. P., Robinson, J. G., West, K., \& Mule, T. (2016). Comparing the U.S. decennial census coverage estimates for children from the demographic analysis and coverage measurement surveys. Population Research and Policy Review, 35(5), 685-703.

O'Hare, W. P. (2018). Demographic profile of individuals who don't respond to the u.s. census bureau's american community survey question on citizenship. Washington, DC: Georgetown University Center on Poverty and Inequality.

Ross, W. (2018). Reinstatement of a Citizenship Question on the 2020 Decennial Census Questionnaire. Memorandum from Secretary of Commerce Wilber Ross to Undersecretary of Commerce Karen Dunn Kelley, May 26, 2018. 
U.S. Census Bureau. (2012a). The American Indian and Alaskan Native population: 2010. In T. Norris, L. P. Vines, \& E. M. Hoeffel (Eds.), 2010 census briefs, C2010BR-10, Washington, DC: U.S. Census Bureau.

U.S. Bureau of the Census. (2012b). 2010 Census coverage measurement estimation report: Summary of estimates of coverage for persons in the United States, DSSD 2010 Census Coverage Measurement Memorandum Series 2012, 2010- G-01. Washington, DC: U.S. Census Bureau.

U.S. Office of Management and Budget. (1997). Revisions to the Standards for the Classification of Federal Data on Race and Ethnicity, Statistical Policy Directive 15, Federal Register Notice, October 30.

U.S. Office of Management and Budget. (2001). Guidance on aggregation and allocation of data on race for use in civil rights monitoring and enforcement.

Open Access This chapter is licensed under the terms of the Creative Commons Attribution 4.0 International License (http://creativecommons.org/licenses/by/4.0/), which permits use, sharing, adaptation, distribution and reproduction in any medium or format, as long as you give appropriate credit to the original author(s) and the source, provide a link to the Creative Commons license and indicate if changes were made.

The images or other third party material in this chapter are included in the chapter's Creative Commons license, unless indicated otherwise in a credit line to the material. If material is not included in the chapter's Creative Commons license and your intended use is not permitted by statutory regulation or exceeds the permitted use, you will need to obtain permission directly from the copyright holder. 